deter the late Dr. Chapman from specially requesting Mr. Lowe to investigate the wing muscles of Gould's manakin, having regard to the complicated nuptia] display of this bird.

Mr. Lowe has always taken a deep interest in bird preservation. His being the rare combination of man of science, all-round naturalist and keen sportsman, made him an undoubted leader in this field. To his balanced judgment and wide vision the British Section, International Committee for Bird Preservation, of which he is chairman, owes its success; and the regard with which he is held by other countries was evidenced by his election as chair. man of the European Continental Section in 1938. The preservation of wildfowl has been Mr. Lowe's especial care, and it was owing to his activities that the International Conference on Wildfowl was held in London in 1927. He was mainly instrumental in forming the Wildfowl Inquiry Committee in 1936 which saw early fruit to its labours in the successful passage of the Wild Birds (Ducks and Geese) Protection Act 1939. His achievements for the preservation of wildfowl were recognized by the award of the Verner von Heidenstam Gold Medal by the Swedish Academy of Sciences in 1939.

\section{Institute of Physics: Prof. J. A. Crowther}

To mark their gratitude to Prof. J. A. Crowther for his fourteen years service as its honorary secretary, the past and present members of the Board of the Institute of Physies gave a lunch at Brown's Hotel, London, prior to the annual general meeting of the Institute on May 29. A testimonial was presented to him on behalf of the members of the Institute, recording their thanks for his unstinting service to the profession of physicist, and stating that his many actions and services "illuminate the pages of the Institute's records". During Prof. Crowther's tenure of office the Institute has not only grown in status and prestige, but also its membership roll has increased fourfold. The five branches in Great Britain and the four subject groups dealing with special branches of applied physics have all been established during this time. Among other new activities for which Prof. Crowther was largely responsible should be mentioned: the establishment of certificates in laboratory arts, and of national certificates in applied physics, the series of conferences and exhibitions and summer schools on various aspects of industrial physics, and the preparation of reports on "The Education and Training of Physicists" and on "The Teaching of Mathematics to Physicists"'. During the War, Prof. Crowther did much to ensure that the services of physicists were utilized to the best advantage, and he has continued this important work during the resettlement period. He has represented the Institute on many outside bodies, including the Parliamentary and Scientific Committee, of which he was vice-chairman. Prof. Crowther has now been elected a vice-president of the Institute of Physics, so that it will still be able to draw on his great experience and knowledge of physicists and physics. It will be recalled that Prof. Crowther is also retiring from the chair of physics at the University of Reading which he has occupied since 1924 (see Nature, March 30, p. 401).

\section{Institute of Physics}

AT the annual general meeting of the Institute of Physics held on May 29, the following were elected to take office on October 1: President, Prof. A. M.
Tyndall ; Vice-Presidents, Prof. J. A. Crowther, Dr. H. Lowery and Mr. A. J. Philpot; Honorary Treasurer, Mr. E. R. Davies, Honorary Secretary, Dr. B. P. Dudding; New Ordinary Members of the Board, Dr. A. McCance, Mr. W. S. Vernon, Dr. F. A. Vick. Dr. G. F. C. Searle was elected an honorary fellow of the Institute.

The report for 1945 of the Institute shows that membership increased by 307 , the highest since its foundation in 1918. Early in the year, at the invitation of the Ministry of Education, the Institute accepted the functions assigned to it by the Ministry in connexion with the arrangements for the award of national certificates in applied physics. The Ministry has now issued rules for the scheme and "Notes for the Guidance of Colleges and Schools". Mr. N. Clarke has been appointed to the new post of assistant secretary of the Institute. The report records that the attendance at the conference on "Instruments for the Automatic Controlling and Recording of Chemical and Other Processes", held jointly with the Institution of Chemical Engineers and the Society of Chemical Industry in October, totalled five hundred. The Institute also took an active part in the celebrations of the fiftieth anniversary of the discovery of X-rays. The Australian branch is still active, and the five local branches and three subject groups in Britain held forty-three meetings (some jointly) during the year. Other matters considered by the Board during the past year included "The Code of Practice in Respect of Consulting and Similar Work accepted by Members of Whole-time Academic Staff', prepared by the Joint Council of Professional Scientists, the release from war-time posts and reallocation of scientific men and the index to $\mathrm{X}$-ray diffraction photographs.

\section{Chemical Engineering at Cambridge: Prof. T. R. C. Fox}

EARLY in 1945 the University of Cambridge received from the Shell Group of Oil Companies an offer to endow in the University a chair of chemical engineering. This offer was accepted by the University on March 2, 1945. It has now been announced that Mr. Terence Robert Corelli Fox, of King's College, Cambridge, has been elected into the professorship. Mr. Fox, who was born in 1912, was educated at Regent Street Polytechnic Secondary School and entered Jesus College, Cambridge, in 1930 with a scholarship in natural science. He read engineering and obtained a first class in the Mechanical Sciences Tripos in 1933. During 1933-37 he was employed in Imperial Chemical Industries, Ltd., as technical assistant to the chief engineer at Billingham. In 1937 Mr. Fox returned to Cambridge as a demonstrator in the Engineering Laboratory. $\mathrm{He}$ was elected a fellow of King's College in 1941 and was made a temporary University lecturer in 1944.

\section{Ministry of Food : Scientific Advisers}

Sir JACK Drummond, scientific adviser to the Ministry of Food, and Dr. T. Moran, director of research and deputy scientific adviser, have resigned their appointments with effect from May 31. Sir Jack Drummond is taking up the appointment, previously announced, as director of research to Messrs. Boots Pure Drug Co., Ltd., Nottingham (see Nature, 155,$603 ; 1945)$. Dr. Moran is returning to his post as director of the Cereals Research Station, St. Albans, in charge of the laboratories of the 
Research Association of British Flour Millers. Pending the appointment of a successor to Sir Jack Drummond, Dr. M. Pyke, who has returned to the Ministry's service from the Control Commission for Austria, will take charge of nutritional matters, and Dr. H. R. Barnell will deal with technological problems in regard to particular commodities.

\section{British Association: Forthcoming Meetings}

THE British Association will hold its annual meeting and two conferences during July. As the Association has no meeting-rooms of its own, various societies have generously granted the use of their premises for these occasions. At the annual meeting, to be held in the hall of the British Medical Association on July 20, the president, Sir Richard Gregory, will deliver his address on "Civilization and the Pursuit of Knowledge". Empire and foreign scientific delegates will be entertained at luncheon, and there will be a soirée in the rooms of the Geological Society. On the following day, July 21, the Association will hold an afternoon reception at Down House, which has already been re-opened to the public since the War. On July 8 , a conference will take place in the theatre of the Royal Institution, on the "Dissemination of Scientific Information to the Public, through the Press, Broadcasting, Films, Museums and Exhibits". This conference will be held by the Association in collaboration with the Royal Society and the Empire Scientific Conference. Sir Henry Dale will preside. On July 25, the Association is arranging a conference to discuss the relation of the United Nations Educational, Scientific and Cultural Organisation to the universities, to be held at the Royal Institute of British Architects. There will be sessions on the intra-mural and extra-mural work of universities, and on their international relations. Among the speakers will be Sir Richard Gregory, Sir Alfred Zimmern, Mrs. Layton, Miss Lynda Grier, Dr. Maxwell Garnett, Prof. Bonamy Dobrée, Mr. P. R. Morris and Dr. Julian Huxley.

While this year's annual meeting of the British Association will be exceptional in being held in London on one day only, the pre-war practice of meetings lasting a week and held in provincial centres will be resumed in future. The meeting in 1947 will take place in Dundee, where the meeting in 1939 was cut short by the imminence of war. In 1948 the Association will meet in Brighton.

\section{Handbooks of the British Fauna and Flora}

A CONFErence convened by the Association for the Study of Systematics in Relation to General Biology was held in the rooms of the Linnean Society on May 30 to consider the present position regarding the production of handbooks on the British fauna and flora. Representatives of fifteen biological societies and organisations, whose programmes include this type of work, were present. In his opening remarks, Dr. W. B. Turrill pointed out that the matter had been under review by the Association before the War and that the way had been cleared by the publication of its "Bibliography of Key Works for the Identification of the British Fauna and Flora". There are many groups of animals of which there are neither monographs nor handbooks in existence, and it is most desirable that the existing gaps should be filled. The position with regard to plants is more satisfactory since, although some groups of crypto. gams have no monographs or handbooks and others need revision, the phanerogams are already adequately covered. Capt. C. Diver outlined the work already done and stated that a list, based on the "Key Works", has been prepared to show these gaps. A measure of co-ordination between interested publishing bodies is necessary to obtain some degree of uniformity in treatment and arrangement. Considerable discussion followed during which it became evident that there is a general desire for a complete new series forming a "Fauna et Flora Britannica". The difficulty of finding authors able and willing to write handbooks for certain groups was discussed, as well as the means of financing publication. By the general wish of the meeting, the Association was urged to prepare a scheme, including recommenda. tions regarding scope, format, groups most urgently needing attention and finance, for submission to a similar conference to decide on a line of action.

\section{Conference on Industrial Spectroscopy}

THE newly formed Industrial Spectroscopic Group of the Institute of Physics will hold its first conference during July 5-6 at the Wellcome Research Founda. tion, 183 Euston Road, London, N.W.1. The Conference will review the present status of industrial spectroscopy and will be open to all interested with out charge, whether members of the Institute or not. The meetings on July $5(2.30-7.0$ p.m.) will be devoted to infra-red absorption spectroscopy. The speakers will be Dr. H. W. Thompson, of St. John's College, Oxford, on the significance of absorption spectroscopy for analytical purposes, and Mr. G. F. Lothian, of the South-West Essex Technical College, on equipment for infra-red absorption measurements. The meetings on July 6 (10.0 a.m. -5.0 p.m.) will deal only with emission spectroscopy. Mr. Nickelson, of Woolwich Arsenal, will discuss equipment for spectrographic analysis; Mr. A. Walsh, of the British Non-Ferrous Metals Research Association, will speak on spectroscopic light-sources for the analysis of metals and alloys; Mr. H. T. Shirley, of the Brown-Firth Research Laboratories, on a statistical examination of sources of error in the spectrographic analysis of alloy steel.

\section{Exhibition of Early Medical Manuscripts and Books at Edinburgh}

A SELECTION of books and manuscripts, to illustrate a series of lectures by Dr. Douglas Guthrie on the history of medicine, has been placed on view in the Upper Library Hall of the University of Edinburgh. Included among manuscripts of the thirteenth century are beautifully written copies of the "Breviarium Medicum" of Serapion, a Syrian physician of the ninth century, and of Avicenna's "Canon of Medicine", a favourite text-book, by the "Prince of Arabian Physicians", which retained its popularity for many centuries and is said to be used still by native practitioners in India. There is also a fifteenth century manuscript of the "Regimen of Health of Salerno", the best-known work of that famous school of medicine. It contains a full-page illustration of a medieval physician and one of his patients. A modern manuscript of much interest, on loan from the Royal College of Surgeons of Edinburgh, is a volume of notes of lectures on surgery, delivered by Lister while he was at Glasgow, containing the first written account of his "antiseptic principle". Among the printed books the greatest rarity is "Christianismi Restitutio", published in 1553 by Michael Servetus, 